\title{
KONSTRUKSI KOPETENSI PROFESIONAL SARJANA EKONOMI SYARIAH PADA LEMBAGA KEUANGAN SYARIAH
}

\author{
Misnen Ardiansyah, Ibnu Qizam, dan Joko Setyono \\ Dosen Fak. Syari'ah Universitas Islam Negeri (UIN) Sunan Kalijaga Yogyakarta \\ misnen_ardy@yahoo.com, q_zami@yaboo.com, setyo_belsa17@yahoo.com
}

\begin{abstract}
This study aims to analyze the perception of either students of higher education institutions of Islamic economics, or that of Islamic financial institutions, or that of institutions of sharia industry concerned with the competence of Islamic economics scholars. Data were obtained through the distribution of questionnaires in universities and branch offices of Islamic financial institutions in Yogyakarta selected by purposive sampling method. The analytical techniques used to address the hypothesis in this study was path analysis using the Partial Least Square (PLS) version 1.01 .

The results showed there is a positive influence of higher education institutions' perceptions on students'perceptions in the development of competence. However, both higher education institutions' perceptions and students' perceptions had no effect on the perception of the industry. This shows that there is still a gap between the competencies developed by higher education institutions and industrial needs.
\end{abstract}

Key words: Competence of Islamic Economics Scholars, Perception of Higher Education Institutions, Perception of Sharia Industry

\begin{abstract}
Abstrak
Penelitian ini bertujuan untuk menganalisis persepsi perguruan tinggi dan mahasiswa program studi ekonomi Islam serta persepsi industri lembaga keuangan syariab tentang kompetensi sarjana ekonomi syariah. Data diperoleh melalui penyebaran kuesioner di perguruan tinggi dan kantor cabang lembaga keuangan syariab terpilib di Daerab Istimewa Yogyakarta dengan metode purposive sampling. Adapun teknik analisis yang digunakan untuk menjawab bipotesis dalam penelitian ini adalah analisis jalur path analysis) dengan menggunakan program Partial Least Square (PLS) versi 1.01.

Hasil penelitian menunjukkan babwa ada pengarub positif persepsi PT terhap dap persepsi mahasiswa dalam pengembangan kompetensi. Namun, persepsi PT maupaun persepsi mahasiswa tidak berpengarub terhadap persepsi industri. Hal ini menunjukkan babwa masib ada kesenjangan antara kompetensi yang dikembangakan perguruan tinggi dengan kebutuban Industri.
\end{abstract}

Kata kunci: Kompetensi Sarjana Ekonomi Syariah, Persepsi Perguruan Tinggi, Persepsi Industri Syariah 


\section{Pendahuluan}

Ekonomi syariah sepertinya telah menjadi pilihan bagi pengembangan ekonomi dunia. Salah satu indikator yang bisa dilihat adalah dengan semakin banyaknya perbankan asing yang membuka layanan bank syariah. Tingginya pertumbuhan industri keuangan syariah membutuhkan dukungan tenaga sumber daya manusia yang profesional. Deputi Gubernur Bank Indonesia, Muliaman D. Hadad, menyatakan bahwa dalam $4-5$ tahun ke depan, diperlukan sekitar 40.000 tenaga kerja yang bergerak khusus di perbankan syariah. Direktur Utama BRI Syariah, Ventje Rahardjo, mengemukakan bahwa kebutuhan SDM perbankan syariah diperkirakan mencapai angka 45.000 orang hingga tahun 2015. Kebutuhan SDM tersebut akan semakin meningkat dengan semakin banyaknya unit-unit perbankan syariah, termasuk microbanking, yang dikembangkan di daerah-daerah. Selama ini SDM di perbankan syariah masih didominasi oleh lulusan yang berlatar belakang non-syariah (Syaukat, 2010).

Ketidaktersediaan sarjana profesional di bidang ekonom syariah menyebabkan kebutuhan tenaga profesional di bisnis syariah yang terus berkembang dipenuhi dengan mengkonversi dari tenaga-tenaga konvensional "tenaga syariah karbitan" yang tidak professional di bidangnya. Tingginya kebutuhan SDM Syariah, khususnya di perbankan syariah selama ini masih diisi tenaga professional perbankan konvensional maupun SDI yang berlatar belakang pendidikan umum baik tinggkat SLTA maupun perguruan tinggi, yang hanya memperoleh training singkat sebelum diterjunkan sebagai praktisi pekerja perbankan syariah. Hal ini bisa menjadi bumerang bagi perkembangan ekonomi syariah ke depan. Dengan demikian, praktisi perbankan syari'ah tidak hanya terfokus pada pengejaran target yang ditetapkan demi kepentingan shareholders, tetapi juga berkomitmen pada penerapan nilai-nilai syari'ah untuk mewujudkan sistem dan tatanan perbankan syariah yang sehat dan istiqomah dalam penerapan prinsip syariah, namun teknis perbankan.

Studi ilmu ekonomi Islam di Perguruan Tinggi di Indonesia sebenarnya telah berlangsung lebih dari satu dasawarsa. Namun, berbagai program studi dalam lingkup ilmu ekonomi Islam berlangsung 
dalam kapasitas dan karakteristik kelembagaan Perguruan Tinggi masing-masing. Hingga kini, dalam perkembangan pembelajaran ekonomi Islam belum ada standarisasi nama program studi dan struktur kurikulum yang menjadi dasar keilmuan program studi dan profil dan kompetensi lulusan yang ingin dihasilkan oleh masingmasing program studi. Jurusan/konsentarasi ilmu ekonomi Islam dikembangkan hanya berdasarkan potensi dan minat peserta didik (calon mahasiswa), belum menyelaraskan dengan pohon keilmuan yang seharusnya ada. Dengan pola pengembangan ini maka struktur kurikulum ekonomi Islam terutama dari aspek struktur keilmum ying ingin dikembangkan oleh suatu program studi sering kali terabaikan terutma "silau" dan terjebak oleh perkembangan ekonomi Islam terutama bidang keuangan dan perbankan syariah. Akibatnya pengembangan ekonom Islam di Indonesia hanya terbatas dalam bidang keuangan dan perbankan syariah dan belum menyentuh keluasan aspek-aspek lain dalam ekonom Islam. Belum ada harmonisasi antara pelaku bisnis syariah dengan akademisi dalam membangun/menyongsong perekembangan ekonomi syariah. Akibatnya, seringkali kebutuhan tenaga kerja sesuai dengan kebutuhan bisnis syariah tidak dapat disediakan oleh pengelola Perguruan Tinggi, sebaliknya pengembangan keilmuan di Perguruan Tinggi penyelanggara program ekonomi Islam belum selaras dengan kebutuhan pasar (bisnis syariah). Permasalahan yang sangat mendasar adalah Bagaimana persepsi pengelola/dosen, mahasiswa, serta praktisi pengguna lulusan prodi pendidikan ekonomi Islam (industri perbankan syariah) tentang kompetensi lulusan program studi ekonomi Islam di Indonesia, khususnya di Daerah Istimewa Yogyakarta.

\section{Keterbatasan SDM di Industri Perbankan Syariah}

Perkembangan perbankan syariah di Indonesia dalam satu dekade terakhir ini sangat pesat. Hal ini terlihat dari semakin tumbuh dan berkembangnya industri perbankan Islam di tanah air, dan semakin tingginya tingkat kepercayaan masyarakat. Meskipun total asset perbankan syariah baru sebesar 3,39\% dari total aset perbankan nasional, namun prospek perbankan syariah ke depannya sangat cerah, apalagi mengingat pangsa pasarnya yang sangat 
besar (Alamsyah, 2011), sehingga wajar jika banyak bank-bank konvensional yang membuka cabang syariah secara langsung maupun melalui konversi cabang-cabang konvensionalnya menjadi cabang syariah.

Dalam perekonomian yang semakin terbuka, pengaruh global semakin terasa bukan saja perbankan Islam yang berhubungan dengan perbankan konvensional, namun juga antara entitas bisnis yang ada di Indonesia dengan yang ada di luar negeri. Bisnis yang bernafaskan Islam mulai marak muncul di mana-mana, seperti bisnis disektor keuangan seperti bank, leasing, modal ventura, asuransi, pasar modal, dana pensiun, pegadaian, kartu plastik, anjak piutang, lembaga amil zakat, dan koperasi, maupun bisnis lain yang berhubungan langsung dengan kebutuhan masyarakat seperti bisnis waralaba, rumah makan, hotel, pendidikan dan lain-lain. Namun, kepesatan tumbuh dan berkembangnya bisnis Islam ini tidak diimbangi dengan upaya penyediaan SDM yang sesuai untuk mendukung keberhasilan bisnis tersebut. Hingga 2014, perbankan syariah setidaknya membutuhkan 9.000 tenaga kerja. Menyediakan tenaga kerja sebanyak itu tidak mungkin dilakukan oleh masingmasing bank. Hal ini dikarenakan setiap bank maksimal hanya mampu menyediakan sekitar 35 orang setiap tahun yang direkrut lewat pendidikan, sedangkan yang dibutuhkan berjumlah ribuan. Kebutuhan tenaga kerja yang jumlahnya ribuan itu, mengacu pada perkembangan bank syariah selama ini terus meningkat (Republika, 6/12/2010).

Keterbatasan SDM yang menguasai aspek syariah sekaligus memiliki wawasan dan keahlian yang memadai dalam bidang ekonomi dan keuangan syariah juga diraskan Bank Indonesia. Berdasarkan penyampaian Outlook Perbankan Syariab tahun 2011 diketahui bahwa di antara kendala percepatan market share perbankan syariah karena faktor SDM, baik di sisi minimnya jumlah SDM perbankan syariah maupun kualitasnya yang masih rendah (Tim BPS BI, 2010). Untuk itu, saat ini Bank Indonesia sedang merancang kebijakan yang diberi nama Grand of Human Capital Strategy. Menurut Pemimpin Bank Indonesia (BI) Semarang, Amril Arief, perbankan syariah di Indonesia perlu memiliki sumber daya manusia (SDM) andal yang mampu memahami prinsip-prinsip kesyariahan. 
Selama ini masih banyak SDM perbankan syariah berasal dari bank konvensional sehingga kondisi itu menyebabkan penerapan sistem bagi hasil (murabahah) agak ditinggalkan. Hal itu perlu menjadi pemicu perbankan syariah untuk memiliki SDM andal yang memahami prinsip syariah. Deputi Gubernur BI, Siti Fajriyah mengatakan bahwa perkembangan perbankan syariah secara kuantitatif, ternyata tidak didukung dengan ketersedian SDM yang mencukupi. Kebutuhan SDM untuk bank syariah mencapai 40.000 orang per tahun, sementara lulusan ekonomi syariah sangat terbatas, minimnya stok lulusan perguruan tinggi yang paham dengan ekonomi syariah membuat sebagian bank khususnya yang membuka office channeling memilih mentransfer pegawai dari bank konvensional. Ini menjadi langkah instan, yang sebenarnya tidak bagus. Para pegawai itu sudah terbiasa dengan mindset bank konvesional, dan tiba-tiba mereka harus mengubah pemikirannya. Salah satu dampak dari cara instan tersebut adalah ketidakpuasan nasabah bank syariah, karena para pegawainya tidak bisa menjelaskan prinsip-prinsip ekonomi syariah dengan baik (Asnaini, 2008: 35-49). Deputi Gubernur Bank Indonesia, Muliaman D Hadad, menyatakan bahwa dalam $4-5$ tahun ke depan, diperlukan sekitar 40.000 tenaga kerja yang bergerak khusus di perbankan syariah. Sementara itu Direktur Utama BRI Syariah, Ventje Rahardjo, mengemukakan bahwa kebutuhan SDM perbankan syariah diperkirakan mencapai angka 45.000 orang hingga tahun 2015. Kebutuhan SDM tersebut akan semakin meningkat dengan semakin banyaknya unit-unit perbankan syariah, termasuk microbanking, yang dikembangkan di daerah-daerah (Syaukat, 2010).

\section{Perguruan Tinggi sebagai Pemasok Tenaga Profesional Industri Keuangan Syariah}

Untuk menjaga citra perekonomian syariah dan kelanggengan perkem-bangannya yang pesat, diperlukan penyediaan SDM yang kompeten melalui Program Pendidikan Tinggi Ekonomi Islam dan Pelatihan (Amalia, 2010). Dalam hal penyediaan SDM yang kompeten, program-program studi Ekonomi Syariah yang tersebar di beberapa Perguruan Tinggi Negeri dan Swasta (PTN dan PTS) di 
Indonesia merupakan sumber utama penyediaan (supply) SDM yang dibutuhkan tersebut, karena mereka telah dipersiapkan (dididik dan dilatih) secara matang untuk dapat memahami filosofi, teori dan praktek Ekonomi Syariah. Namun, proses pendidikan formal tersebut membutuhkan waktu relatif lama, paling tidak 3 atau 4 tahun, sehingga kebutuhan (demand) yang ada dalam periode waktu tersebut tidak mungkin dapat terpenuhi. Untuk mengatasi hal ini, dapat dikembangkan program-program pendidikan dan pelatihan sistem ekonomi syariah bagi SDM terdidik alumni dari PTN dan PTS yang belum bekerja atau bagi karyawan perbankan/ non-perbankan konvensional yang akan ditempatkan di lembaga perbankan/non-perbankan syariah. Tujuannya adalah agar syariah compliance-praktek perekonomian syariah yang sesuai dengan kaidah-kaidah fiqih Islam- dapat dilaksanakan. Sistem pendidikan dan latihan semacam ini tidak membutuhkan waktu yang terlalu lama, mungkin antara 3-6 bulan termasuk on the job training (magang).

\section{Pengembangan Kurikulum Ekonomi Islam}

Dari beberapa faktor yang mempengaruhi kualitas lulusan suatu lembaga pendidikan, kurikulum dianggap menjadi prioritas utama untuk diperhatikan. Hal ini tidak lain karena kurikulum merupakan rencana pendidikan yang akan diberikan kepada mahasiswa. Bahkan dalam pengertian lebih luas, keberadaan kurikulum tidak saja terbatas pada materi yang akan diberikan di dalam ruang kuliah, melainkan juga meliputi apa saja yang sengaja diadakan atau ditiadakan untuk dialami mahasiswa di dalam kampus (Agustianto, 2011). Oleh karena itu, posisi kurikulum menjadi mata rantai yang urgen dan tidak dapat begitu saja dinafikan dalam konteks peningkatan kualitas perguruan tinggi.

Kurikulum adalah seperangkat materi pendidikan dan pengajaran yang diberikan kepada peserta didik atau suatu rencana yang disusun untuk melancarkan proses belajar-mengajar di bawah bimbingan dan tanggungjawab sekolah atau lembaga pendidikan beserta staf pengajarnya. Ralp Tayler dalam "Basic Principles of Curriculum and Instruction," berpendapat ada empat faktor 
penentu dalam perencanaan kurikulum, yakni faktor filosofis, sosiologis, psikologis dan epistimologis (Agustianto, 2011). Faktorfaktor ini, terutama faktor sosiologis, mengalami perkembangan sangat dinamis, sehingga menuntut evaluasi untuk melakukan pengembangan serta perubahan kurikulum secara periodik. Namun, karena aspek sosiologis ini juga berbeda antara satu tempat dengan tempat lain, maka di samping penyeragaman kurikulum secara nasional, perlu juga pengembangan kurikulum sesuai dengan kondisi dan potensi lokal masing-masing lembaga pendidikan.

Salah satu hambatan dalam pengembangan ekonomi keuangan syariah di Indonesia adalah masalah kurikulum pengajaran ekonomi keuangan syariah yang belum berbasis kompetensi. Dalam hal ini, kurikulum yang ada harus jelas arahannya apakah diperuntukkan bagi calon praktisi maupun calon akademisi. Selain berbasis kompetensi, kurikulum yang ada saat ini harus komperhensif-integratif antara nilai-nilai syariah dengan masalah ekonomi keuangan. Sangat disayangkan bila kurikulum ekonomi Islam yang digunakan saat ini tidak disesuaikan dengan perkembangan yang ada.

Peran institusi pendidikan, termasuk perguruan tinggi, beserta kurikulumnya menjadi sangat signifikan dalam memenuhi kebutuhan SDM yang memiliki kualifikasi yang memadai. Ada beberapa langkah yang dapat dilakukan oleh perguruan tinggi, yaitu antara lain: Pertama, memperbaiki dan menyempurnakan kurikulum pendidikan ekonomi, dimana sudah saatnya ada ruang bagi pengkajian dan penelaahan ekonomi Islam secara lebih mendalam dan aplikatif. Bahkan sebaiknya dibukanya jurusan ekonomi Islam secara tersendiri, dimana ilmu ekonomi Islam dikembangkan dengan memadukan pendekatan normatif keagamaan dan pendekatan kuantitatif empiris, yang disertai oleh komprehensivitas analisis. Kedua memperbanyak riset, studi, dan penelitian tentang ekonomi Islam, baik yang berskala mikro maupun makro. Ini akan memperkaya khazanah keilmuan dan literatur ekonomi Islam, sekaligus sebagai alat ukur keberhasilan penerapan sistem ekonomi Islam di Indonesia; dan yang ketiga mengembangkan networking yang lebih luas dengan berbagai institusi pendidikan ekonomi Islam lainnya, lembaga-lembaga 
keuangan dan non keuangan Islam, baik di dalam maupun luar negeri, seperti IDB maupun kalangan perbankan Islam di dalam negeri. Adanya kesamaan langkah ini insya Allah akan mendorong percepatan sosialisasi dan implementasi ekonomi Islam di negeri tercinta ini.

Pengembangan kurikulum memerlukan landasan pijakan yang kuat, seperti landasan filosofis, landasan psikologis, landasan sosiologis, dan landasan organisatoris. Landasan filosofis menawarkan beberapa pertanyaan mendasar seperti: (a) siapakah hakikat pebelajar; (b) apakah yang seharusnya dilakukan pebelajar; (c) tugas-tugas apakah yang harus dilakukan pendidik/instruktur;, dan (d) apakah yang harus menjadi isi kurikulum (Suharno, 2009: 2). Jawaban atas keempat pertanyaan tersebut bermanfaat untuk menentukan ke arah mana pebelajar akan dibawa; memberi gambaran tentang hasil/perilaku atau kompetensi apa yang harus dikuasai pebelajar; menentukan cara dan proses untuk mencapai tujuan itu; memberikan kesatuan dan kebulatan kepada usaha pendidikan; memungkinkan pendidik/instruktur menilai usahanya sejauhmana tujuan pendidikan itu tercapai; dan memberi motivasi bagi kegiatan-kegiatan pendidikan. Landasan psikologis berkaitan dengan peramalan dan pengendalian tingkah laku, perasaan dan pikiran pebelajar. Landasan sosiologis berhubungan dengan upaya mengaitkan kurikulum dengan kebutuhan dan keberadaan masyarakat, dengan penekanan utama pada kemampuan fungsi kurikulum memecahkan aneka problem yang dihadapi masyarakat. Dengan demikian, kurikulum harus ada relevansinya dengan kehidupan dan kebutuhan masyarakat. Landasan organisatoris maksudnya bentuk penyajian bahan ajar dapat mempertimbangkan 3 (tiga) hal, yaitu materi ajar satu dengan yang lainnya terpisah (separate subject curriculum); antara materi ajar satu dengan yang lainnya saling berhubungan dalam penyampaiannya (correlated curriculum); atau materi-materi ajar itu dapat disajikan dalam bentuk unit (integrated curriculum) (Suharno, 2009: 2-3).

Secara prinsip ada dua model penyusunan kurikulum, yaitu model subject matter dan model kompetensi/topik inti. Model subject matter menggunakan pola deduktif dalam penyusunan kurikulumnya yaitu dengan cara menentukan 
struktur kurikulum atau mata kuliah sebagai patokan. Akan tetapi, model KBK menggunakan pola induktif dalam penyusunannya yaitu, penyusunan kurikulum dan penentuan mata kuliah didasarkan pada pengalaman belajar yang harus diberikan pada pemahaman mahasiswa yang dirumuskan dalam pencapaian kompetensi yang telah dirancang. Bagi pengelolaan pendidikan yang sedang berjalan dengan pengalaman yang memadai dalam mengaplikasikan kurikulum dengan model subject matter dan dalam perkembangannya mengorientasikan pelaksanaan kurikulumnya/ pembelajarannya pada basis kompetensi, maka pola pengembangan kurikulumnya biasa menggunakan pola deduktif-induktif, sehingga pengembangan kurikulum tersebut didasarkan pada penyusunan standar isi yang didalamnya menyangkut standar kompetensi (SK), kompetensi dasar (KD), dan struktur kurikulum (Dantes, 2009: 12).

Model KBK ini diharapkan dapat menghasilkan: (1) pengelolaan kurikulum yang dapat membantu mahasiswa mengembangkan potensi diri secara optimal dan sesuai dengan tuntutan pangsa pasar; (2) peningkatan kualitas lulusan sesuai dengan kompetensi yang diharapkan sehingga sesuai dengan kebutuhan riil di masyarakat; (3) pencapaian kompetensi dengan berorientasi pada mastery learning yang berbasis pada penilaian otentik dan proses; dan (4) sikap otonomi pengelolaan pembelajaran dengan meningkatkan peranan jurusan dan staf dosen dalam mengembangkan berbagai inovasi pembelajaran demi peningkatan kualitas lulusan (Dantes, 2009: 9).

Perlu diterapkan strategi penetapan kompetensi utama. Dalam hal ini, yang dilakukan adalah dengan mengidenfikasi kompetensi yang sangat diperlukan dan paling banyak dijumpai pada setiap jenis jabatan/pekerjaan yang mungkin ditempati oleh lulusan. Tahapan yang perlu dilakukan dalam menetapkan kompetensi utama ialah:

1) Mengidentifikasi jabatan/pekerjaan yang mungkin ditempati oleh lulusan;

2) Mengidentifikasi kompetensi generik untuk setiap jabatan/ pekerjaan;

3) Mengidentifikasi kompetensi profesional dan kompetensi bidang 
keahlian untuk tiap jabatan/pekerjaan sesuai dengan program studi;

4) Mengidentifikasi variabel-variabel eksternal yang mempengaruhi karakteristik dunia kerja seperti kondisi sosial dan ekonomi, perkembangan teknologi, dan perubahan budaya;

5) Mendefinisikan karakteristik instansi pengguna lulusan;

6) Mengidentifikasi trend perubahan pasar kerja berdasarkan bidang masing-masing

7) Mengidentifikasi kompetensi profil lulusan berdasarkan jabatan/ pekerjaan, misalnya teknisi, arsitek, akuntan, hakim, jaksa, dan advokat.

Bila langkah di atas telah dilakukan, dilanjutkan dengan pemetaan kompetensi. Kompetensi yang paling sering dijumpai dan sangat diperlukan pada setiap jabatan pekerjaan dapat dipertimbangkan sebagai kompetensi utama. Sedangkan kompetensi lain yang telah diidentifikasi dapat dijadikan sebagai kompetensi pendukung dan kompetensi khusus. Selanjutnya kompetensi yang telah ditetapkan akan dijabarkan lebih lanjut dengan pengisian elemenkompetensi yang terbagi kepada lima bagian yaitu: (1) Landasan kepribadian; (2) Penguasan ilmu dan ketrampilan; (3) Kemampuan berkarya; (4) Sikap dan perilaku dalam berkarya; dan (5) Pemahaman kaidah berkehidupan bermasyarakat. Berdasarkan kompetensi utama yang telah diidentifikasi dapat dijabarkan menjadi elemen-elemen kompetensi, untuk selanjutnya dikemas menjadi mata kuliah-mata kuliah yang terkait dan dikembangkan menjadi kurikulum inti. Untuk mempermudah hal ini perlu dibuat suatu mapping yang memperlihatkan bidang dunia kerja, bidang keilmuannya dan kompetensi yang terkait.

\section{Pengembangan Pendidikan Tinggi Ekonomi Islam}

Untuk melahirkan SDI yang berkompeten di bidang bisnis dan hukum syari'ah secara komprehensif dan memadai, serta memiliki integritas tinggi, maka dibutuhkan lembaga pendidikan ekonomi syari'ah yang secara khusus menyiapkan SDI ekonomi syari'ah. Karena itu perlu adanya redesign tentang institusi kependidikan 
di Indonesia terutama di fakultas ekonomi dan syariah, agar dapat dihasilkan sarjana yang mempunyai keahlian tentang ekonomi syari'ah dan memiliki budi pekerti yang sesuai dengan syariah Islam dan dapat diaplikasikan di sektor ekonomi.

Masalah SDM Perbankan syariah yang dihadapi saat ini memerlukan pengembangan sistem pendidikan terutama ekonomi Islam yang diarahkan pada "pendidikan yang bersinerji" anatara pemerintah, BI dan Perguruan Tinggi (Amalia, 2011). Pemerintah sebagai penanggung jawab terlaksananya pendidikan yang baik, untuk mengkomunikasikannya kepada Bank Indonesia (BI) sebagai lembaga tertinggi dan pembina perbankan Indonesia, lalu BI dan Bank Syari'ah berkoordinasi pada Perguruan Tinggi untuk mendidik dan menyiapkan output yang dibutuhkan, sehingga dengan komunikasi ini mahasiswa tidak dikorbankan, setelah tamat mereka dengan mudah dapat menerapkan ilmu yang diperoleh dalam dunia kerja sesuai dengan kompetensi yang dimiliki. Pendidikan seperti inilah yang disebut dengan pendidikan yang sejalan dengan kebutuhan pasar dan akhirnya manusia akan dapat mengoptimalkan dirinya dalam menjalankan tugas kekhalifaannya di bumi dan menjadi manusia ke-Tuhan-an, yaitu bermanfaat bagi alam semesta.

\section{Metode Penelitian}

Penelitian ini adalah penelitian eksplanatori yang bermaksud untuk memberikan penjelasan hubungan kausalitas antar variabel melalui pengujian hipotesis sekaligus melakukan eksplanasi. Penelitian ini juga termasuk survei dengan mengambil sampel dari populasi yang menggunakan instrumen kuesioner.

Populasi pada penelitian ini adalah pengelola/dosen dan mahasiswa semester akhir (yang sedang menempuh sekripsi) program studi ekonomi Islam serta pimpinan/karyawan Lembaga Keuangan Syariah pemakai lulusan program studi ekonomi Islam di Daerah Istimewa Yogyakarta. Jumlah sampel yang digunakan dalam penelitian ini adalah 87 sampel secara purposive. Analisis data yang digunakan dalam penelitian adalah analisis jalur (path analysis). Analisis jalur yang digunakan dalam menguji hipotesis menggunakan Partial Least Square (PLS) menggunakan program SmartPLS Versi 1.01. 


\section{Uji Validitas dan Reliabilitas}

Uji validitas dilakukan dengan menggunakan analisis faktor konfirmatori (confirmatori factor analysis) pada masing-masing variabel laten yaitu Persepsi Perguruan Tinggi, Persepsi Mahasiswa, dan Persepsi Industri dengan menggunakan program PLS Versi 1.01. Apabila nilai loading factor pada indikator lebih besar dari 0,5; maka indikator dapat digunakan untuk mengukur variabel. Hasil uji Validitas dalam penelitian ini ditunjukkan dalam Gambar 1.

Reliabilitas dalam penelitian ini dihitung dengan menggunakan composite (construct) reliability dengan cut off value minimal sebesar 0,6. Hasil perhitungan composite (construct) reliability ditunjukkan dalam Tabel 1. Dari tabel tersebut dapat dilihat bahwa konstruk Persepsi Perguruan Tinggi, Mahasiswa, dan Industri sangat reliabel karena memiliki nilai composite reliability masing-masing sebesar 0.993, 0,996, dan 0,994 jauh lebih besar dari nilai cut off minimal sebesar 0,6.

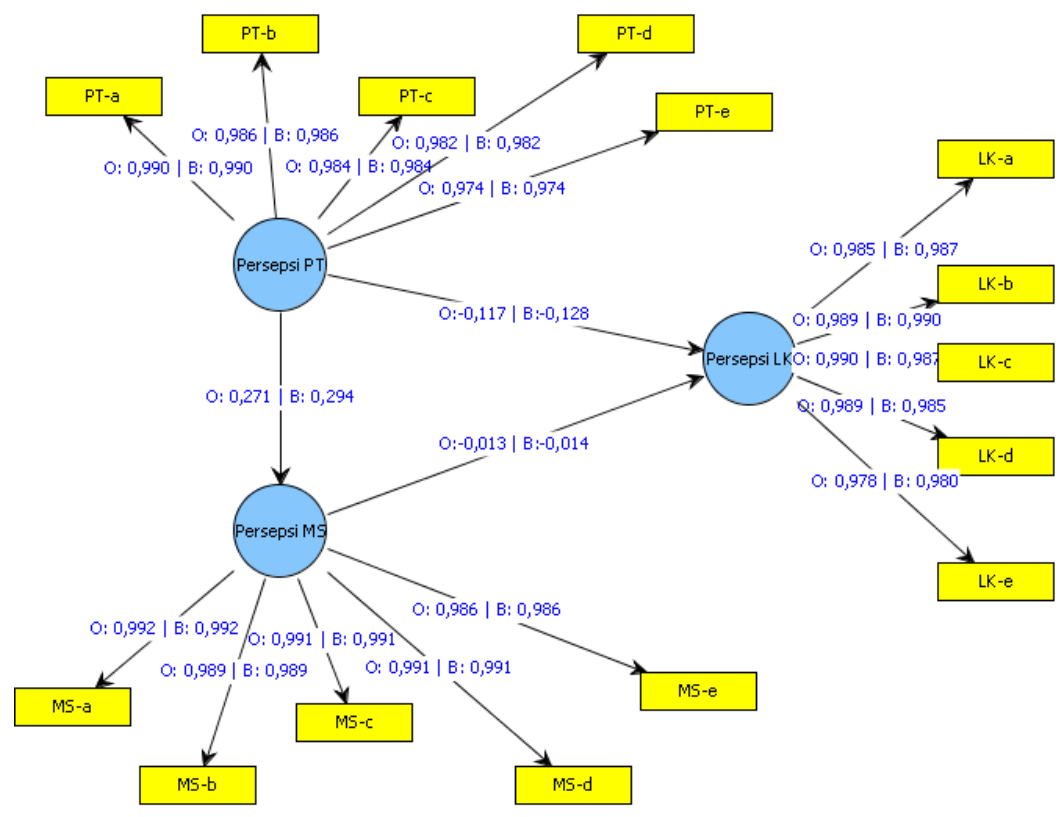

Gambar 1.

\section{Hasil Uji Validitas Instrumen Penelitian}


Tabel: 1

Composite Reliability

\begin{tabular}{|c|c|}
\hline & Composite Reliability \\
\hline Persepsi PT & 0.993 \\
\hline Persepsi MS & 0.996 \\
\hline Persepsi LK & 0.994 \\
\hline
\end{tabular}

Sumber : Hasil pengolahan dengan PLS.

Keseluruhan variabel dalam penelitian ini diukur dengan nilainya sendiri sehingga nilai masing-masing bobotnya adalah 1,00 dengan signifikansi 0,00. Hal ini berarti bahwa semua variabel studi ini sudah diukur dengan ukuran yang identik dengan dirinya atau sudah tepat dalam pengukuran variabel.

\section{Analisis}

Berdasarkan hasil pengujian koefisien jalur sebagaimana disajikan pada Tabel 2 maka hipotesis satu signifikan pada tingkat 0,05, karena $p$-value $<0,05$. Sedangkan hipotesis dua dan tiga dinyatakan tidak signifikan pada tingkat 0,05, karena p-value $>0,05$.

Tabel: 2

\section{Pengujian Koefisien Jalur}

\begin{tabular}{|c|c|c|c|c|}
\hline \multicolumn{2}{|c|}{} & $\begin{array}{c}\text { Koefisien } \\
\text { Estimasi }\end{array}$ & t-statistik & p-value \\
\hline$H_{1}$ & $\begin{array}{c}\text { Pengaruh Persepsi Perguruan Tinggi } \\
(\text { PT) terhadap Persepsi Mahasiswa (MS) }\end{array}$ & 0,271 & 2,792 & 0,005 \\
\hline$H_{2}$ & $\begin{array}{c}\text { Pengaruh Persepsi Perguruan Tinggi } \\
\text { (PT) terhadap Persepsi Industri (LK) }\end{array}$ & $-0,117$ & 1,014 & 0,311 \\
\hline$H_{3}$ & $\begin{array}{c}\text { Pengaruh Mhasiswa (MS) terhadap } \\
\text { Persepsi Industri (LK) }\end{array}$ & $-0,013$ & 0,126 & 0,900 \\
\hline \multicolumn{7}{|c|}{$\begin{array}{c}\text { R-Square Variabel Endogen Persepsi Mahasiswa } \\
\text { R-Square Variabel Endogen Persepsi Industri }\end{array}$} & $\begin{array}{c}=0,074 \\
=0,015\end{array}$ & \\
\hline
\end{tabular}

*: Signifikan pada tingkat 0,05

Sumber : Hasil pengolahan dengan PLS. 
Persepsi Perguruan Tinggi Penyelenggara Program Studi Ekonomi Islam tentang Kompetensi Lulusan Ekonomi Islam.

Berdasarkan data yang digunakan dan pengujian yang telah dilakukan menunjukkan bahwa perguruan tinggi telah mengembangkan kompetensi lulusan sesuai dengan ketentuan yang ada. Hal ini dapat dilihat dari mayoritas responden $(41,1 \%)$ menjawab setuju telah membekali mahasiswa dengan kompetensi yang dibutuhkan sebagai sarjana ekonomi Islam. Kompetensi yang dirancang juga telah sesuai dengan kurikulum dan metode pembelajaran yang dikembangkan. Dari beberapa faktor yang mempengaruhi kualitas lulusan suatu lembaga pendidikan, barangkali kurikulumlah yang bisa dianggap menjadi prioritas utama untuk diperhatikan. Hal ini tidak lain karena kurikulum merupakan rencana pendidikan yang akan diberikan kepada mahasiswa. Bahkan dalam pengertian lebih luas, keberadaan kurikulum tidak saja terbatas pada materi yang akan diberikan di dalam ruang kuliah, melainkan juga meliputi apa saja yang sengaja diadakan atau ditiadakan untuk dialami mahasiswa di dalam kampus. Oleh karena itu, posisi kurikulum menjadi mata rantai yang urgen dan tidak dapat begitu saja dinafikan dalam konteks peningkatan kualitas perguruan tinggi.

Ada empat faktor penentu dalam perencanaan kurikulum, yakni faktor filosofis, sosiologis, psikologis dan epistimologis. Faktorfaktor ini, terutama faktor sosiologis, mengalami perkembangan sangat dinamis, sehingga menuntut evaluasi untuk melakukan pengembangan serta perubahan kurikulum secara periodik. Namun, karena aspek sosiologis ini juga berbeda antara satu tempat dengan tempat lain, maka di samping penyeragaman kurikulum secara nasional, perlu juga pengembangan kurikulum sesuai dengan kondisi dan potensi lokal masing-masing lembaga pendidikan. Mengingat kurikulum adalah program layanan pendidikan yang ditawarkan atau 'dijual' kepada masyarakat, maka seharusnya kurikulum dipandang sebagai jati diri program studi ekonomi Islam. Kurikulum program studi ekonomi Islam harus mencerminkan identitas lembaga tersebut sebagai perguruan tinggi yang bermutu (melakukan pendidikan, pengembangan ilmu/penelitian, dan pengabdian kepada masyarakat di bidang ekonomi Islam). Di 
samping itu ia harus mencerminkan misi dan visi perguruan tinggi, fakultas atau program studi ekonomi Islam tersebut. Kurikulum juga harus memberikan gambaran yang jelas tentang lulusan yang ingin dihasilkan dan bagaimana lembaga pendidikan tersebut akan mewujudkan lulusan yang profesional dan berkualitas. Lembaga pendidikan ekonomi syariah juga harus menunjukkan keistimewaannya jika dibandingkan dengan perguruan tinggi sejenis, khususunya dengan fakultas ekonomi konvensional atau Sekolah Tinggi Ilmu Ekonomi yang konvensional. Mengingat kurikulum inilah yang sebenarnya 'dibeli' atau yang menarik minat masyarakat, maka kurikulum harus dikemas sedemikian rupa hingga dapat meyakinkan masyarakat bahwa mereka tidak akan rugi kalau belajar di lembaga pendidikan yang bersangkutan, tetapi beruntung karena memiliki keunggulan dan added value dari lainnya. Penampilan dan bahasa dalam kurikulum itu harus menarik dan meyakinkan pembaca. Pembaca harus diyakinkan bahwa program pendidikan di lembaga pendidikan tinggi ekonomi Islam tersebut telah dirancang dengan cermat dan rapi sehingga tidak akan membuang waktu, tenaga, dan dana mahasiswa yang belajar di tempat itu.

\section{Persepsi Perguruan Mahasiswa Program Studi Ekonomi Islam tentang Kompetensi Lulusan Ekonomi Islam.}

Berdasarkan data yang digunakan dan pengujian yang telah dilakukan menunjukkan bahwa perguruan tinggi telah mengembangkan kompetensi lulusan sesuai dengan ketentuan yang ada. Mahasiswa di Perguruan Tinggi penyelenggara Program Studi Ekonomi Islam telah dibekali kompetensi sebagai sarjana ekonomi Islam. Hal ini dapat dilihat dari mayoritas responden $(46,9 \%)$ menjawab setuju bahwa mereka telah dibekali dengan kompetensi yang dibutuhkan sebagai sarjana ekonomi Islam. Kompetensi yang dirancang juga telah sesuai dengan metode pembelajaran yang dikembangkan.

Salah satu hambatan dalam pengembangan ekonomi keuangan syariah di Indonesia adalah masalah kurikulum pengajaran ekonomi keuangan syariah yang belum berbasis kompetensi. Sehingga kurikulum yang ada harus jelas arahannya apakah 
diperuntukkan bagi calon praktisi maupun calon akademisi. Selain berbasis kompetensi, kurikulum yang ada saat ini harus komperhensif-integratif antara nilai-nilai syariah dengan masalah ekonomi keuangan.

Penyusunan kurikulum ekonomi Islam di Perguruan Tinggi mencakup hal-hal berikut:

a. Kurikulum berbasis kompetensi yang dapat pembedaan kurikulum untuk calon praktisi dengan kurikulum untuk calon akademisi.

b. Kurikulum yang mampu mengintegrasikan nilai-nilai syariah, terutama masalah fikih muamalah dengan materi kuliah ekonomi keuangan secara komprehensif.

c. Kurikulum yang membekali mahasiswa dengan ilmu-ilmu kuantitatif, terkait dengan pengembangan nalar dan logika.

d. Kurikulum yang mengintegrasikan antara teori dengan praktik, sehingga calon praktisi lembaga keuangan syariah harus dilengkapi dengan laboratorium praktik lembaga keuangan dan juga program magang di lembaga perbankan dan keuangan syariah.

Hasil dari pengembangan kurikulum yang baik akan menghasilkan lulusan dengan kulaitas SDI yang mumpuni, antara lain:

a. Memahami nilai-nilai moral dalam aplikasi fikih muamalah/ ekonomi syariah;

b. Memahami konsep dan tujuan ekonomi Syariah;

c. Memahami konsep dan aplikasi transaksi-transaksi (akad) dalam muamalah ekonomi syariah;

d. Mengenal dan memahami mekanisme kerja lembaga ekonomi/ keuangan/ perbankan/bisnis syariah;

e. Mengetahui dan memahami mekanisme kerja dan interaksi lembaga-lembaga terkait regulator, pengawas, lembaga hukum, dan konsultan dalam industri ekonomi/keuangan/perbankan/ bisnis syariah;

f. Mengetahui dan memahami hukum dasar baik hukum syariah (fiqh mumalah) maupun hukum positif yang berlaku;

g. Menguasai bahasa sumber ilmu, yaitu Bahasa Arab dan Inggis. 
Pengarub Persepsi Perguruan Tinggi terhadap Persepsi Mahasiswa.

Berdasarkan data yang digunakan dan pengujian yang telah dilakukan menunjukkan persepsi PT berpengaruh terhadap persepsi mahasiswa dengan hubungan positif. Hal ini menunjukkan bahwa ada korelasi positif antara persepsi PT dengan mahasiswa dalam pengembanan kompetensi dan pembelajaran mahasiswa di program studi ekonomi Islam.

Kompetensi yang dikembangkan di Perguruan Tinggi diharapkan dapat menghasilkan: (1) pengelolaan kurikulum yang dapat membantu mahasiswa mengembangkan potensi diri secara optimal dan sesuai dengan tuntutan pangsa pasar; (2) peningkatan kualitas lulusan sesuai dengan kompetensi yang diharapkan sehingga sesuai dengan kebutuhan riil di masyarakat; (3) pencapaian kompetensi dengan berorientasi pada mastery learning yang berbasis pada penilaian otentik dan proses; dan (4) sikap otonomi pengelolaan pembelajaran dengan meningkatkan peranan jurusan dan staf dosen dalam mengembangkan berbagai inovasi pembelajaran demi peningkatan kualitas lulusan.

\section{Pengaruh Persepsi Perguruan Tinggi terhadap Persepsi Industri.}

Berdasarkan data yang digunakan dan pengujian yang telah dilakukan menunjukkan persepsi PT tidak berpengaruh terhadap persepsi industri. Hal ini menunjukkan bahwa masih ada kesenjangan antara kompetensi yang dikembangakan perguruan tinggi dengan kebutuhan Industri. Belum ada harmonisasi antara pelaku bisnis syariah dengan akademisi dalam mengembangakan kompetensi Ekonomi Islam di Perguruan Tinggi. Akibatnya, seringkali kebutuhan tenaga kerja sesuai dengan kebutuhan bisnis syariah tidak dapat disediakan oleh pengelola Perguruan Tinggi, sebaliknya pengembangan keilmuan di Perguruan Tinggi penyelanggara program ekonomi Islam belum selaras dengan kebutuhan pasar (bisnis syariah).

Lembaga pendidikan adalah institusi yang bertanggung jawab dalam menghasilkan SDM keuangan syariah yang berkualitas. Dalam pengembangan pendidikan ekonomi keuangan syariah di masa yang akan datang setidaknya ada lima aspek yang 
perlu mendapat perhatian serius, Pertama, Set kurikulum yang tepat; mengkombinasikan mata kuliah yang memberikan pengetahuan profesionalitas ekonomi/ keuangan/perbankan/ bisnis dan pengetahuan syariah (hukum \& aplikasi) serta nilainilai moral (akidah \& akhlak); Kedua Tersedia sarana dan fasilitas belajar yang memadai; matrikulasi bahasa, perpustakaan (literatur lengkap), laboratorium (bank, akuntansi dll); Ketiga, Staf pengajar yang kompeten dan berkualitas; Keempat, Buku teks yang memadai (perpustakaan yang menyediakan buku dan litaratur ekonomi Islam); Kelima, Program pendukung seperti; magang, on-job training dsb.

\section{Pengaruh Persepsi Mahasiswa terhadap Persepsi Industri.}

Berdasarkan data yang digunakan dan pengujian yang telah dilakukan sebagaimana disajikan sebelumnya menunjukkan persepsi mahasiswa tidak berpengaruh terhadap persepsi industri. Hal ini menunjukkan bahwa masih ada kesenjangan antara harapan industri dengan mahasiwa tentang kompetensi sarjana Ekonomi islam. Alasan ini diperkuat dengan masih banyaknya lembaga keuangan syariah khususnya perbankan yang masih menggunakan tenaga karbitan dari bank konvensional, karena dianggap mereka lebih profesional.

Sebagian besar SDM bank syariah, terutama pada level menengah dan atas, adalah pindahan dari bank konvensional dengan berbagai motif dan berlatarbelakang pendidikan non syariah. Sehingga pada tataran teoritis dan konseptual, kita masih merasakan sangat kekurangan SDI yang benar-benar mendalami ilmu ushul fikih, fikih muamalah, qawa'id fikih dan sekaligus ilmu ekonomi keuangan modern. Figur seperti ini benar-benar langka bukan saja bagi masyarakat Islam di Indonesia melainkan juga di banyak negara termasuk negara lain yang perkembangan ekonomi Islamnya cukup pesat. Kebanyakan SDI LKS saat ini adalah mereka yang fasih berbicara tentang ilmu ekonomi keuangan kontemporer, tetapi awam dalam ushul fiqh atau fiqh muamalah. Sebaliknya banyak pakar yang mahir dalam Fikih dan Usul Fiqh tetapi kurang memahami Ilmu Ekonomi Keuangan. Untuk melahirkan SDI yang berkompeten di bidang ekonomi, bisnis dan 
hukum ekonomi syari'ah secara komprehensif dan memadai, serta memiliki integritas tinggi, maka dibutuhkan lembaga pendidikan ekonomi syari'ah yang secara khusus menyiapkan SDI ekonomi syari'ah.

Sementara itu, lembaga pendidikan ekonomi keuangan syariah pada umumnya menghadapi sejumlah kendala dalam upaya mengembangkan kualitas. Kendala itu antara lain: (1) keterbatasan ahli ekonomi keuangan syariah, yang menguasai secara komprehensif ilmu ekonomi, keuangan sekaligus ilmu syariah, (2) keterbatasan dari segi kurikulum pengajaran, kurikulum belum berbasis kepada kompetensi, (3) belum ada linkage antara lembaga pendidikan dengan lembaga keuangan Syariah, dan (4) keterbatasan dana dan SDM sehingga research dan laboratorium penelitian di bidang ilmu ekonomi dan keuangan syariah masih terbatas.

Untuk melahirkan SDI yang berkompeten di bidang bisnis dan hukum syari'ah secara komprehensif dan memadai, serta memiliki integritas tinggi, maka dibutuhkan lembaga pendidikan ekonomi syari'ah yang secara khusus menyiapkan SDI ekonomi syari'ah. Karena itu perlu adanya redesign tentang institusi kependidikan di Indonesia terutama di fakultas ekonomi dan syariah, agar dapat dihasilkan sarjana yang mempunyai skills tentang ekonomi syari'ah dan memiliki budi pekerti yang sesuai dengan syariah Islam dan applicable di sektor ekonomi.

\section{Kesimpulan}

Berdasarkan data yang digunakan dan pengujian yang telah dilakukan dapat disimpulkan bahwa: Perguruan Tinggi telah mengembangkan kompetensi lulusan sesuai dengan kebutuahan sarjana ekonomi Islam. Kompetensi yang dirancang juga telah sesuai dengan metode pembelajaran yang dikembangkan. Mahasiswa di Perguruan Tinggi penyelenggara Program Studi Ekonomi Islam telah dibekali kompetensi sebagai sarjana ekonomi Islam.

Persepsi PT berpengaruh terhadap persepsi mahasiswa dengan hubungan positif. Hal ini menunjukkan bahwa ada korelasi positif antara persepsi PT dengan mahasiswa dalam pengembangan 
kompetensi dan pembelajaran mahasiswa di program studi ekonomi Islam. Persepsi PT tidak berpengaruh terhadap persepsi industri. Hal ini menunjukkan bahwa meskipun kompetensi lulusan sesuai dengan yang seharusnya dikembangkan oleh lembaga pendidikan ekonomi Islam, namun belum sesuai dengan harapan indusri tentang tenaga yang siap beroperasi di bisnis syariah. Oleh karena itu perlu ada harmonisasi antara pelaku bisnis syariah dengan akademisi dalam mengembangkan kompetensi Ekonomi Islam di Perguruan Tinggi. Persepsi mahasiswa tidak berpengaruh tern hadap persepsi industri. Hal ini menunjukkan bahwa masih ada kesenjangan antara harapan industri dengan mahasiswa tentang kompetensi sarjana Ekonomi Islam. Alasan ini diperkuat dengan masih banyaknya lembaga keuangan syariah khususnya perbankan yang masih menggunakan tenaga karbitan dari bank konvensional, karena dianggap mereka lebih profesional. Hal ini menunjukkan bahwa pengembangan kurikulum dan praktik bisnis syariah masih berjalan sendiri-sendiri. Perlu ada mediasi untuk membangun kurikulum yang bermutu yang bisa mencerminkan kebutuhan ahli perbankan syariah.

\section{Daftar Pustaka}

Abdullah, Amin. 2008., Gelombang Orientalisme dan Studi-Studi Islam Kontemporer, dalam Menjadi Indonesia, 13 Abad Eksistensi Islam di Bumi Nusantara, Mizan, hlm.111.

Abdul Mannan. 2005. Teori dan Praktek Ekonomi Islam, Yogyakarta; PT Dana Bhakti Wakaf, hlm. 311.

Agustianto, 2011, Menyiapkan SDM Ekonomi Syariah melalui Perguruan Tinggi Ekonomi Islam, http://www.pkesinteraktif. com/edukasi/opini/223-menyiapkan-sdm-ekonomi-syariahprofesional-melalui-perguruan-tinggi-ekonomi-islam.html

Agustianto, 2011, Meningkatkan Kompetensi SDM Ekonomi Syari'ah http://www.agustiantocentre.com/?p=445

Alamsyah, Halim. 2011. Proceding Intrnational Seminar Islamic Finance and Its Global Chalenges, Semarang: UNISSULA, 11 Mei.

Anoraga, Pandji. 2000. Manajemen Bisnis. Jakarta: Rineka Cipta. 
Anonymous. 2009. "Menggodok Kurikulum-Menyiapkan SDM Andal", Majalah Sharing Edisi April, Jakarta, h. 22.

Asnaini. 2008. "Pengembangan Mutu SDM Perbankan Syari'ah: Sebagai Upaya Pengembangan Ekonomi Islam", La_Riba Jurnal Ekonomi Islam, Vol 2. No. 1, p. 35-49.

Boulakia, Jean David C., "Ibn Khaldun: A Fourteenth Century Economist"- Journal of Political Economiy 79 (5) September -October 1971

Chapra, M. Umer. 1999. Islam dan Tantangan Ekonomi, a.b Nurhadi Ihsan, Rifqi Amar, (Surabaya: Risalah Gusti, cet.I).

Cooper, Donal R. and C. William Emory. 1995. Business Research Methods, 5th edition, Chicago: Richard D. Irwin Inc.

Dantes, Nyoman. 2009. "Kurikulum Berbasis Kompetensi di Perguruan Tinggi“, makalah dipresentasikan dalam Lokakarya Kurikulum Fakultas Seni Rupa dan Disain, Institut Seni Indonesia, Denpasar, 18 November.

Dawam Rahardja. 1999. Islam dan Transformsi Sosial-Ekonomi, Lembaga Studi Agama dan Filsafat, Jakarta.

Deliarnov. 2003. Perkembangan Pemikiran Ekonomi, cetakan ketiga, Jakarta: Divisi Buku Perguruan Tinggi PT Raja Grafindo Persada.

Departemen Agama RI, Al-quran dan Terjemahannya.

Euis Amalia. 2011. "Potret Pendidikan Ekonomi Islam di Indonesia dan Upaya Pembaharuan Kurikulum Ekonomi Islam dalam Menghasilkan SDM Integratif." Disampaikan dalam Semiloka Nasional (Re)orientasi Pembidangan dan Standarisasi Kurikulum Ilmu Ekonomi Islam, Yogyakarta 14-15 Juli.

Ferdinand, Augusty. 2002., Structural Equation Modelling dalam Penelitian Manajemen, edisi 2, Semarang: Fakultas Ekonomi Undip.

Ghozali, Imam. 2005. Struktur Equation Modeling: Teori, Konsep, E Aplikasi dengan Program Lisrel 8.54, Semarang: Badan Penerbit Universitas Diponegoro.

. 2006. Structural Equation Modeling: Metode Alternatif dengan Partial Least Square. Semarang: Badan Penerbit Universitas Diponegoro. 
Ghozali, Imam dan Fuad, 2005, "Structural Equation Modeling. Teori, Konsep dan Aplikasi," Semarang: Badan Penerbit Universitas Diponegoro.

Halim Alamsyah. 2011. Deputi Gubernur Bank Indonesia, Proceding Intrnational Seminar Islamic Finance and Its Global Chalenges, Semarang: UNISSULA, 11 Mei.

Hamalik, Oemar. 2003. Proses Belajar-Mengajar, Jakarta: Bumi Aksara.

Hanafi, Syafiq Mahmada. 2006. Prinsip Ekonomi Islam: Tinjauan terhadap Keberhasilan dalam Perekonomian, Mazhab Jogja ke-2: Pembaharuan Pemikiran Hukum Islam (Yogyakarta: Penerbit Fakultas Syari'ah UIN Sunan Kalijaga), hlm. 257-317.

Handoko, T. Hani. 2001. Manajemen Personalia Dan Sumberdaya Manusia, Edisi Kedua, BPFE, Yogyakarta.

Hasanuzzaman. 1984. "Definition of Islamic Economics", Journal of Research in Islamic Economics, Vol. I, No .2, dalam Abd. Salam Arif, Ushul Fiqh dalam..., hlm. 202.

Hasibuan, SP, Malayu. 2001. Manajemen Sumber Daya Manusia, Edisi Revisi. Jakarta: Bumi Aksara.

Hasibuan, Malayu. 2002. Manajemen Sumber Daya Manusia. Edisi Revisi. Jakarta: Penerbit Bumi Aksara.

Indriantoro, Nur dan Bambang Supomo. 1999. Metodologi Penelitian Bisnis Untuk Akuntansi dan Manajemen. Edisi Pertama. Yogyakarta: BPFE.

Jihad, Asep dan Abdul Haris. 2010. Evaluasi Pembelajaran, Yogyakarta: Multi Pressindo.

Jujun S. Suriasumantri, Filsafat Ilmu Sebuah Pengantar Populer, Jakarta: Pustaka Sinar Harapan, hlm. 19.

Kast Fremont. 1991. Organisasi dan Manajemen, edisi 4. Jakarta: Bumi Aksara.

Kerlinger, Fred N., 1993. Foundations of Behavior Research, Third Edition, diterjemahkan oleh L.R. Simatupang, Jogjakarta: Gajah Mada University Press.

Kompas, 22/12/2007. Yokyakarta, laporan Eny Prihtiyani.

Karim, A. Adiwarman. 2001, Islamic Microeconomic (Jakarta: Muammalat Institute). 
Miarso, Yusufhadi. 2006, Pembelajaran di Perdosenan Tinggi : Isu-isu Aktual Saat ini, makalah dipresentasikan pada 28 Agusutus.

Manan, M. A., 1995., Teori dan Praktek Ekonomi Islam, (Yogyakarta; PT Dana Bhakti Wakaf).

Manullang, M dan Marihot Manullang. 2001. Manajemen Personalia. Yogyakarta: Gadjah Mada University Press.

Metwally, M.M., 1995. Teori dan Model Ekonomi Islam (terj), Jakarta: Bangkit Daya Insani.

Nawawi, Hadari. 2003. Manajemen Sumber Daya Manusia Untuk Bisnis yang Kompetitif. Yogyakarta: Gadjah Mada University Press.

Nanih Machendrawaty dan Agus Ahmad Safei. 2001. Pengembangan Masyarakat Islam. Bandung: Rosdakarya.

Pusat Pengkajian dan Pengembanan Ekonomi Islam (LP3I) UII atas kerjasama dengan Bank Indonesia. 2008. Ekonomi Islam, Jakarta: Raja Grafindo Persada.

Samuelson, Paul and William Nordhau. 2001. Economic, Irwin McGraw-Hill, New York.

Siagian, Sondang P., 2006. Manajemen Sumber Daya Manusia. Edisi Pertama. Jakarta: Bumi Aksara.

Solimun. 2002. Structural Equation Modeling, Lisrel dan Amos, Malang: Fakultas MIPA, Universitas Brawijaya

Suara merdeka, minggu 1 juli 2007. Yogyakarta, CyberNews.

Sudarsono, Heri. 2004. Konsep Ekonomi Islam: Suatu Pengantar (Yogyakarta: Ekonisia Fakultas Ekonomi UII).

Suharno. 2009. "Reorientasi Pengembangan Kurikulum di Perguruan Tinggi “, Jurnal AKADEMIKA, Vol. 1 No. 1, Januari, h. 2, diterbitkan oleh Universitas Negeri Solo (UNS).

Syaukat, Yusman. 2010. "Urgensi Pemenuhan SDM Ekonomi Syariah" dalam http://mirror.unpad.ac.id/koran/republika/2010-08-26/ republika_2010-08-26_008.pdf. Diakses pada 4 Oktober.

Shiddiqy, Muhammad Nejatullah. 1976. Muslim Economic Thinking, A Survey of Contemporary Literature, dalam buku Studies in Islamic Economics, International Centre for Research in Islamic Economics, King Abdul Aziz Jeddah and The Islamic 
Foundation, United Kingdom.

Tim PEKERTI-AA PPSP LPP Universitas Sebelas Maret. 2007. Panduan Pengembangan Kurikulum, Surakarta: Universitas Sebelas Maret.

Tim Peneliti UI, 2011, "Presentasi Seminar Penelitian UI Tahun 2003", Jakarta: UI, 2008, dalam Euis Amalia, Potret Pendidikan Ekonomi Islam.

Tim BPS BI. 2010. "Outlook Perbankan Syariah Tahun 2011", Jakarta: BI.

Umar, Husein. 1997. Metodologi Penelititan: Aplikasi dalam Pemasaran, Jakarta: PT Gramedia.

Veithzal Rivai. 2009. "Akselerasi Petumbuhan Ekonomi Indonesia melalui Pembentukan Program Studi Ekonomi Islam di Fakultas Ekonomi Perguruan Tinggi Muhammadiyah," disampaikan dalam Semiloka Ekonomi Islam Ekonomi Islam Sebagai Sistem Pendidikan Ilmu Ekonomi di Indonesia, Surakarta, 13-14 Februari.

Widoyoko, Eko Putro. 2009. Evaluasi Program Pembelajaran: Panduan Praktis bagi Pendidik dan Calon Pendidik, Yogyakarta: Pustaka Pelajar.

Dirjen Dikti. 2006. "Keputusan Direktur Jenderal Pendidikan Tinggi Departemen Pendidikan Nasional RI No. 44/DIKTI/ Kep./2006 tentang Rambu-Rambu Pelaksanaan Mata Kuliah Berkehidupan Bermasyarakat di Perdosenan Tinggi."

www.yahoo.com/Sumber daya manusia.

www.yahoo.com/Perbankan syariah.

www.yahoo.com/Bank Indonesia.

www. annashuhakalimukti.org/sampai-2030-kebutuhan-sdmsyariah-184-ribu. 